\title{
Effect of polyethylene plastic mulch on yield and fruit quality parameters of tomato
}

\author{
Burak Tüzen (D) 1 , Aslıhan Çilingir Tütüncü (D) 1*, Salim Taşdelen (D) 1 , Aysun Pekşen (D) 1 \\ ${ }^{1}$ Ondokuz Mayıs University Faculty of Agriculture, Department of Horticulture, Samsun-Turkey
}

\begin{abstract}
The greenhouse experiment was conducted to evaluate the effect of black polyethylene (PE) plastic mulch on yield and some quality parameters of tomato. In the study, black PE mulch material was laid on raised beds and bare soil (not mulched) was used as control. Mulch did not affect plant height, fruit shape index, chroma and hue angle, firmness, soluble solids content, titratable acidity. Black PE plastic mulch had a positive influence on yield. Significantly higher stem diameter and yield were obtained from the black PE mulch application (17.23 mm and $18.78 \mathrm{~kg} \mathrm{da}^{-1}$, respectively) compared to the control (15.30 mm and $16.75 \mathrm{~kg} \mathrm{da}^{-1}$, respectively). On the other hand, vitamin $\mathrm{C}$ was higher in control (41.13 $\mathrm{mg} 100 \mathrm{~g}^{-1}$ ) than in the black PE mulch application.
\end{abstract}

\section{ARTICLE HISTORY}

Received: 11 November 2021

Accepted: 16 November 2021

\section{KEYWORDS}

Solanum lycopersicum L. Black PE mulch

Quality

Yield

\section{* CORRESPONDING}

aslihancilingir6155@gmail.com

\section{Introduction}

Turkey is one of the most important vegetable producers in the world. The world's fresh vegetable production is 1.1 billion tons and the production area is 58 million hectares. Turkey ranks fourth globally with approximately 31 million tons of vegetable production among the producer countries (FAO, 2019). Open area vegetable production is 23.2 million tons and 7.8 million tons of production is realized under greenhouse conditions (Republic of Turkey Ministry of Agriculture and Forestry, 2019). Tomato ranks first in Turkey vegetable production with 12.8 million tons (TUIK, 2020). Agronomic practices are important factors that increase yield and quality in tomato cultivation. The weeds that appear in the production areas host lots of diseases and pests, and they also compete with the crops regarding nutrients, water in the soil, and sunlight. This leads to a significant decrease in yield and deterioration of fruit quality. Excessive use of fertilizers and pesticides against diseases, pests, and weeds adversely affects the environment and human health. Therefore, the orientation towards organic vegetable cultivation has increased (Durmuşoğlu et al., 2010; Özer, 2017a,b).

Mulch is preferred in organic vegetable cultivation due to essential benefits such as the use of weed control, conservation of moisture in the soil, increasing soil temperature, control the erosion losses, and remove the residual effects of pesticides, fertilizers, and heavy metals, earliness, and yield increase, protection of fruits against diseases, easiness of drip irrigation and water-saving (Ünlü et al., 2006; Koçar, 2007; Zanic et al., 2009; Özer, 2017a; Iqbal et al., 2020). Many researchers have stated that mulches used in different colors (black, brown, transparent, green, and white) and materials (organic and inorganic) have essential contributions to vegetable growing (Koçar, 2007; Özer et al., 2009; Özer, 2017a). Mulch materials may be inorganic (paper, aluminum, plastic, etc.) or organic (straw, sawdust, animal manure, compost, etc.). In the case of using organic mulches, some problems such as preventing soil warming by organic material that covers the soil surface like a layer, changing the $\mathrm{pH}$ balance, and in some cases nitrogen deficiency can occur. The most commonly used inorganic mulch in the world is polyethylene plastic mulch. The use of plastic mulch in agriculture is increasing day by day. Plastic mulch provides the excellent development of plant roots by causing an increase in soil temperature and encouraging strong growth (Ekinci and Dursun, 2006). Therefore, this study investigated the effects of black plastic mulch on the yield and quality of tomatoes without fertilization.

\section{Materials and methods}

The research was carried out in the unheated plastic greenhouse of Ondokuz Mayis University, Faculty of Agriculture, Department of Horticulture, between 7 April and 28 July 2021. In the study, seedlings of tomato (Solanum lycopersicum L. cv. Erva), indeterminate tomato variety, were used. The plastic greenhouse was in width of $6 \mathrm{~m}$, a length of $20 \mathrm{~m}\left(120 \mathrm{~m}^{2}\right)$, and a side height of $3 \mathrm{~m}$. The raised bed blocks with and without mulch (bare soil) were $9 \mathrm{~m}$ long, $1 \mathrm{~m}$ wide, and $25 \mathrm{~cm}$ high. Burnt animal manure $\left(1 \mathrm{~kg} \mathrm{~m}^{-2}\right)$ was incorporated to $5 \mathrm{~cm}$ soil depth as base fertilizer along the prepared tubes. Drip irrigation pipes have been drawn to be suitable for double-row planting. Afterward, black polyethylene plastic mulch material was covered on the prepared raised bed by randomly dispersing the applications. 
The tomato seedlings cv. Erva were planted on April 7, with $50 \mathrm{~cm}$ between the rows and $50 \mathrm{~cm}$ within the rows. Chemical fertilizers did not apply after planting.

\subsection{Examined parameters}

Plant height $(\mathrm{cm})$ was measured from the root collar to the tip of the plant. The stem diameter (mm) was measured with a digital caliper in the middle of the inter-node between the first and the second node. Yield $\left(\mathrm{kg} \mathrm{da}^{-1}\right)$ was calculated by weighing all harvested fruits. In each experiment replication, ten sampled fruits from both mulch and control treatments were used in the analyses. The fruit shape index (width/length) was calculated by dividing the fruit length by the fruit width. Firmness was removed from 2 different cheeks of the equatorial part of 10 fruits in each replication and then measured by a hand penetrometer (4301, Instron, USA) with a $7.9 \mathrm{~mm}$ tip (Kılıç et al., 1991). The amount of water-soluble dry matter was measured with a digital refractometer (PAL-1, McCormick Fruit Tech. Yakima, USA). Titratable acidity was determined in the samples taken from the existing fruit juice samples. Vitamin C (Lascorbic acid) content (mg vitamin C/100 g fresh weight) was calculated by measuring at $518 \mathrm{~nm}$ wavelength in a spectrophotometer according to AOAC (1995). Color of the fruits was measured in terms of L, A, B using a Minolta color measuring device and hue angle and chroma values were calculated according to the following formula [Hue ${ }^{\circ} \mathrm{h}=\tan ^{-}$ ${ }^{1}$ (b/a) Chroma $\left.C^{*}=\sqrt{ }\left(a^{2}+b^{2}\right)\right]$ (McGuire, 1992). During the growing period, greenhouse temperature $\left({ }^{\circ} \mathrm{C}\right)$, relative humidity (\%) (KT100, Kimo, France) were measured from planting to the end of harvest. The measured values are given in Figure 1.

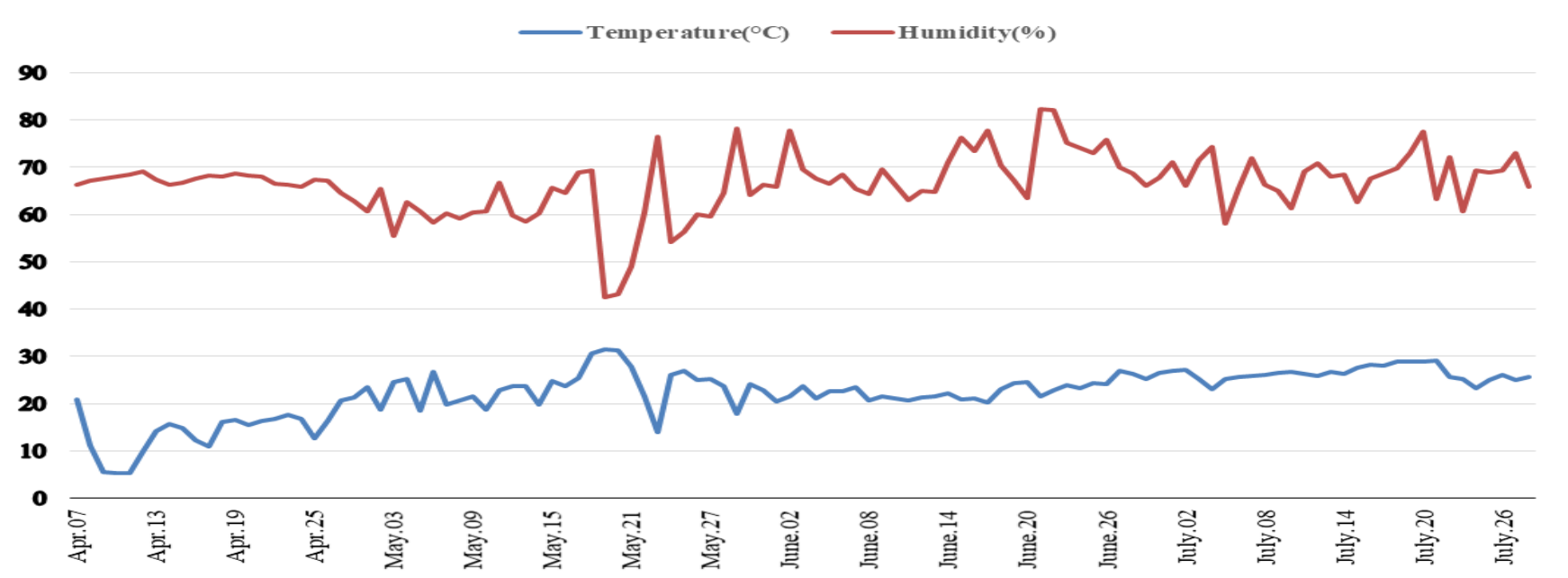

Figure 1. Temperature $\left({ }^{\circ} \mathrm{C}\right)$ and relative humidity (\%) values in a greenhouse during the growth period of tomato

Table 1. The effect of mulch application on plant height, stem diameter, fruit shape index and some fruit quality parameters

\begin{tabular}{|c|c|c|c|}
\hline Investigated parameters & Mulch & Control & $\mathrm{P}$ value \\
\hline Plant height $(\mathrm{cm})$ & 186.11 & 186.32 & $0.97 \mathrm{~ns}$ \\
\hline Stem diameter (mm) & $17.23 \mathrm{a}$ & $15.30 \mathrm{~b}$ & $0.04 *$ \\
\hline Fruit shape index & 1.33 & 1.33 & $0.56 \mathrm{~ns}$ \\
\hline Chroma & 26.11 & 26.53 & $0.72 \mathrm{~ns}$ \\
\hline Hue angle & 51.88 & 51.11 & $0.36 \mathrm{~ns}$ \\
\hline Firmness $\left(\mathrm{kg} / \mathrm{cm}^{2}\right)$ & 4.76 & 5.43 & $0.12 \mathrm{~ns}$ \\
\hline SSC (\%) & 4.35 & 4.55 & $0.23 \mathrm{~ns}$ \\
\hline Titratable acidity (g citric acid $100 \mathrm{~mL}^{-1}$ ) & 2.98 & 3.22 & $0.12 \mathrm{~ns}$ \\
\hline Vitamin C (mg $\left.100 \mathrm{~g}^{-1}\right)$ & $38.86 \mathrm{~b}$ & $41.13 \mathrm{a}$ & $0.01^{*}$ \\
\hline
\end{tabular}

*: The differences between the means are statistically significant $(\mathrm{p}<0.05)$. ns: non-significant

\subsection{Statistical analysis}

The study was carried out in Randomised Complete Block Design with 3 replications. JMP statistical analysis program was used for statistical analysis. The differences between treatments means were compared by the "t-test" $(\mathrm{p}<0.05)$.

\section{Results and discussions}

The plant height of tomatoes was not affected by applying plastic mulches compared to control (bare soil). Among the examined parameters, the significant effects of the applications on stem diameter and yield values were determined $(\mathrm{p}<0.05)$.
The black PE mulch application determined the highest stem diameter (17.23 mm) (Table 1). Total yield was significantly higher for black PE mulch (18.78 $\mathrm{kg} \mathrm{da}^{-1}$ ) when compared to the control (16.75 $\mathrm{kg} \mathrm{da}^{-1}$ ) (Figure 2).

It is thought that black PE mulch application conserves more water in the soil than the control without mulch, accelerates root activity, and increases water and nutrient uptake and transport. Other researchers have reported a significantly higher yield on black PE mulch due to soil moisture conservation, effective soil temperature, and weed control (Seyfi and Rashidi, 2007; Berihun, 2011; Mahadeen, 2014; Tesfaye et al., 2016). The black plastic mulch reduced 
soil water evaporation and improved soil water retention (Mahadeen, 2014). Mulching increased fruit yield and stem diameter based on these positive contributions compared to control treatment where mulch is not used. Many studies have shown that mulch application has a positive effect on yield compared to mulch is not used (Kurtar, 2010; Özer, 2012; Rajablariani et al., 2012). Also, Gordon et al. (2010) stated that plastic mulch produced a higher total yield when compared with other mulches.

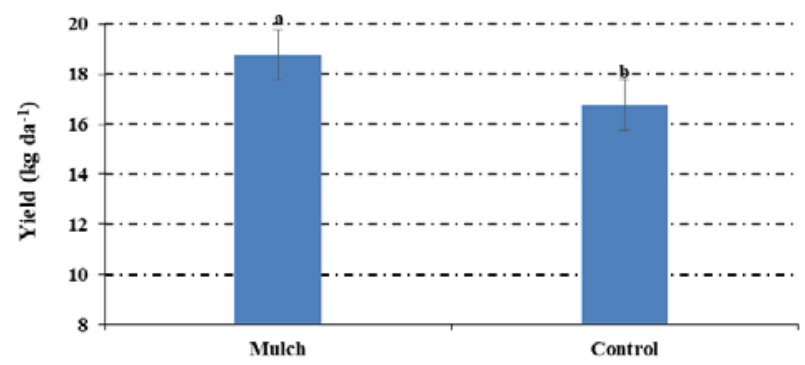

Figure 2. The effect of mulch on the tomato fruit yield (The difference between the means of mulch treatments is statistically significant $(\mathrm{p}<0.05)$

There were no significant differences between mulched and non-mulched control treatments for fruit shape index and colors (chroma and hue angle) (Table 1). In control, fruit firmness $\left(5.4 \mathrm{~kg} / \mathrm{mm}^{2}\right)$, soluble solids content $(4.5 \%)$ and titratable acidity (3.22 g citric acid $100 \mathrm{~mL}^{-1}$ ) values were determined a little bit higher than mulching application. However, there were no significant differences between mulched and non-mulched control treatments for those traits (Table 1). Significant $(\mathrm{p}<0.05)$ variation was recorded between plastic mulch and control treatments for vitamin $C$ content. The vitamin $\mathrm{C}$ content was determined higher in plants grown in control $\left(41.13 \mathrm{mg} 100 \mathrm{~g}^{-1}\right)$ than that in the mulching application (38.86 mg $100 \mathrm{~g}^{-1}$ ) (Table 1). Alagöz et al. (2020) reported that vitamin $C$ values of tomatoes grown in different planting systems (raised bed and flat) and the green manure treatments ranged between 17.55 and $24.50 \mathrm{mg} 100 \mathrm{~g}^{-1}$. The vitamin $\mathrm{C}$ content of tomato is affected by genetic factors, temperature and light from environmental factors, water and nutrient content from soil conditions, and harvest maturity (Ilıć et al., 2012).

\section{Conclusion}

The study investigated the effect of mulch use on yield and quality parameters in tomato cultivation. According to the results, it was determined that the yield and stem diameter parameters were higher in mulch treatment than the control. At the same time, vitamin $\mathrm{C}$ content was higher in the control group. According to the findings, it is thought that the mulch application keeps the heat and moisture more, encourages plant growth, and therefore increases the yield and stem diameter values. However, the high vitamin $C$ content in the control group suggests that tomato plants increase their vitamin $C$ content under stress conditions. Overall, mulch is recommended in vegetable cultivation because of its benefits, such as preventing weed growth, protecting plant roots and soil from adverse environmental conditions, and increasing yield and quality.

\section{Compliance with Ethical Standards}

\section{Conflict of Interest}

The authors have no conflict of interest to declare.

\section{Authors' Contributions}

Burak Tüzen: Project administration and writing manuscript. Aslıhan Çilingir Tütüncü: Project administration, data analyses, writing manuscript. Salim Taşdelen: Project administration and writing manuscript. Aysun Pekşen: Conducting test and analyses, editing manuscript. All authors accepted the manuscript.

\section{Ethical approval}

Not applicable.

\section{Funding}

No financial support was received for this study.

\section{Data availability}

Not applicable.

\section{Consent for publication}

Not applicable.

\section{References}

Alagöz, G., Özer, H., \& Pekşen, A. (2020). Raised bed planting and green manuring increased tomato yields through improved soil microbial activity in an organic production system. Biological Agriculture \& Horticulture, 36(3), 187-199.

Berihun, B. (2011). Effect of mulching and amount of water on the yield of tomato under drip irrigation. Journal of Horticulture and Forestry, 3(7), 200-206.

Durmuşoğlu, E., O. Tiryaki \& Canhilal, R. (2010). Türkiye'de Pestisit Kullanımı, Kalıntı ve Dayanıklılık Sorunları. Türkiye Ziraat Mühendisliği 7. Teknik Kongresi, 11-15 Ocak 2010, Ankara. Bildiriler Kitab1 2, 589-607.

Ekinci, M., \& Dursun, A. (2006). Sebze yetiştiriciliğinde malç kullanımı. Derim, 23(1), 20-27.

FAO (2019). Bitkisel üretim istatistikleri. http://www.fao.org/faostat.(Erişim tarihi:05.10.2021).

Gordon, G.G. Foshee, G. W., Reed, S.T., Brown, J.E., \& Vinson, E.L. (2010). The effects of colored plastic mulches and row covers on the growth and yield of Okra. HortTechnology, 20(1), 224-233.

Ilıć, ZS., Milenković, L., Šunić, L., Stanojević, L., BodrožaSolarov, M., Marinković, D. (2012). Tomato fruits quality as affected by light intensity using color shade nets. $47^{\text {th }}$ Croatian and 7th Int Sym Agric, Proceedings, pp. 414-418.

Iqbal, R., Raza, M. A. S., Valipour, M., Saleem, M.F., Zaheer, M. S., Ahmad, S., Toleikiene, M., Haider, I., Aslam, M.U. \& Nazar, M.A. (2020). Potential agricultural and environmental benefits of mulches - A review. Bulletin of the National Research Centre, 44, 1-16.

Kılıç, O., Çopur, U.Ö., \& Görtay, Ș. (1991). Meyve ve sebze ișleme teknolojisi uygulama kılavuzu. Uludağ Üniversitesi Ziraat Fakültesi Yayınları: Ders Notları: 7, s. 147, Bursa.

Koçar, G. (2007). Farklı renklerdeki malç materyallerinin sera marul yetiştiriciliğinde verim ve kaliteye etkileri. Ege Tarımsal Araştırma Enstitüsü Dergisi, 11(1), 47-55.

Kurtar, E. (2010). Isıtmasız cam serada sonbahar dönemi yazlık kabak (Cucurbita pepo L.) yetiştiriciliğinde malç 
uygulamalarının etkileri. Harran Tarım ve Gıda Bilimleri Dergisi, 14(2), 69-76.

Mahadeen, A.Y. (2014). Effect of polyethylene black plastic mulch on growth and yield of two summer vegetable crops under rainfed conditions under semi-arid region conditions. American Journal of Agricultural and Biological Sciences, 9(2), 202-207.

Özer, H. (2012). Organik Domates (Solanum lycopersicum L.) Yetiştiriciliğinde Değişik Masura, Malç Tipi ve Organik Gübrelerin Büyüme, Gelişme, Verim ve Kalite Üzerine Etkileri. Ondokuz Mayıs Üniversitesi Fen Bilimleri Enstitüsü, 158.

Özer, H. (2017a). Organic tomato (Solanum lycopersicum L.) production under different mulches in greenhouse. The Journal of Animal \& Plant Sciences, 27(5), 1565-1572.

Özer, H. (2017b). Effects of shading and organic fertilizers on tomato yield and quality. Pakistan Journal of Botany, 49(5), 1849-1855.

Özer, H., Kandemir, D., \& Uzun S. (2009). İlk turfanda organik biber yetiştiriciliğinde farklı malç uygulamalarının büyüme ve verime etkisi. 1. GAP Organik Tarım Kongresi 17-20 KasımŞanlıurfa. S: 784-790.

Rajablariani, H., Rafezi, R., \& Hassankhan, F. (2012). Using colored plastic mulches in tomato (Lycopersicon esculentum
L.) production. In $4^{\text {th }}$ International Conference on Agriculture and Animal Science. IPCBEE (Vol. 47, pp. 12-16).

Republic of Turkey Ministry of Agriculture and Forestry. (2019). https://www.tarimorman.gov.tr/Konular/Bitkisel-

Uretim/Tarla-Ve-Bahce-Bitkileri/Ortu-Alti-Yetistiricilik (Erişim tarihi:13.11.2019).

Seyfi, K., \& Rashidi, M. (2007). Effect of drip irrigation and plastic mulch on crop yield and yield components of cantaloupe. International Journal of Agriculture and Biology, 9(2), 247249.

Tesfaye, T., Tigabu, E., Gedamu, Y., \& Lemma, H. (2016). Effect of colored polyethylene mulch on soil temperature, growth, fruit quality and yield of tomato (Lycopersicon esculentum Mill.). World Journal of Agricultural Sciences, 12(3), 161-166.

TUIK, (2020). www.tuik.gov.tr (Erişim tarihi:05.10.2020).

Ünlü, Ö.H., Ünlü, H., Karataş, A., Padem, H., \& Kitiş, Y.E. (2006). Farklı renkteki malçların domateste verim ve kalite özelliklerine etkisi. Alatarım, 5 (1), 10- 14.

Zanic, K., Ban, D., Ban, G.S., Culjak, G.T. \& Dumicic, K. (2009). Response of alate aphid species to mulch colour in watermelon. Journal of Food, Agriculture \& Environment, 7(3), 496-502.

Copyright: (C) 2021 by the authors. Turkish Journal of Food and Agriculture Sciences is licensed under a Creative Commons AttributionNonCommercial-NoDerivatives 4.0 International License 